\title{
0 jovem Nietzsche e as instituições de formação alemãs
}

\author{
The young Nietzsche and the German institutions of formation
}

\author{
Alexander Gonçalves* \\ Antônio Carlos de Souza
}

\section{Resumo}

De um modo geral, o posicionamento do jovem Nietzsche frente às instituições de formação alemãs (deutsche Bildungsanstalten) se encontra na esteira de sua crítica à formação (Bildung) e deve ser compreendido no âmbito maior de seu projeto de reforma (ou reedificação) da cultura alemã (deutsche Kultur). Partindo da análise da crítica nietzschiana à formação (Bildung) alemã, primeiramente pela via do filisteu da formação (Bildungsphilister) e em seguida pela via dos estabelecimentos de formação alemães, nosso escopo será mostrar de que modo a língua materna, para o jovem Nietzsche, constitui um elemento fundamental para a formação do homem, bem como para a constituição da cultura de um povo. Isso justifica a preocupação nietzschiana com o seu tratamento por parte dos filisteus da formação, bem como com o seu ensino nas instituições de formação alemãs, que, para o jovem filólogo, deve ser conduzido de forma rigorosa e sempre sob a batuta do gênio.

Palavras-chave: Bildung. Cultura. Estilo. Língua.

\section{Abstract}

In general, the position of the young Nietzsche in front of the german institutions of formation (deutsche Bildungsanstalten) is in the wake of his criticism of formation (Bildung) and must be understood in the larger scope of his project of reform of german culture (deutsche Kultur). Starting from the analysis of the nietzschean critique of german formation, first through the philistine formation (Bildungsphilister) and then by the german formation establishments, our scope will be to show how the mother tongue, for the young Nietzsche, constitutes a fundamental element for the formation of the man, as well as for the constitution of the culture of a people. This justifies the nietzschean concern with his treatment by the Philistines of formation, as well as with their teaching in the German training institutions which for the young philologist must be conducted rigorously and always under the baton of genius.

Keywords: Bildung. Culture. Style. Language.

Recebido em: 15/02/2017 - Aprovado em: 12/07/2017

http://dx.doi.org/10.5335/rep.v24i3.7764

Doutor em Filosofia pela Universidade de São Paulo. Professor no Colegiado de Filosofia do Centro de Ciências Humanas e Educação da Universidade Estadual do Norte do Paraná. E-mail: alexandergoncalves@uenp.edu.br

** Doutor em Educação pela Universidade Estadual de Campinas. Professor no Colegiado de Filosofia do Centro de Ciências Humanas e Educação da Universidade Estadual do Norte do Paraná. E-mail: acsouza@uenp.edu.br 
Na primeira extemporânea, Nietzsche define o conceito de cultura nos seguintes termos: "Cultura [Kultur] é antes de tudo a unidade de estilo [Stil] artístico de todas as manifestações da vida de um povo" (2011a, p. 643, tradução nossa). ${ }^{1}$ Uma relação de reciprocidade é estabelecida entre os conceitos de cultura e estilo e, nesse sentido, pensar um implica necessariamente pensar o outro. Também em sua segunda extemporânea, o filósofo retoma a oposição entre cultura e barbárie já apresentada em seu escrito sobre David Strauss, porém com alguns ajustes:

A cultura [Kultur] de um povo, como antagonismo de toda barbárie, tem sido definida em certa ocasião, tenho entendido que com certa razão, como unidade de estilo artístico em todas as manifestações vitais de um povo; esta definição não deve ser entendida mal, como se se tratasse de um contraste entre barbárie e estilo "belo"; o povo a que se atribui uma cultura simplesmente deve, em toda realidade, ser uma unidade vivente e não dissociar-se de uma maneira tão lamentável em interior e exterior, em conteúdo e forma. Quem quer anelar e promover a cultura de um povo há de anelar e promover esta unidade superior e cooperar na destruição da moderna tendência à erudição [Gebildetheit] em favor de uma formação verdadeira [wahren Bildung] [...] (NIETZSCHE, 2011b, p. 713).

O estado de barbárie em que se encontrava a Alemanha do século XIX, segundo Nietzsche, não está relacionado à má produção artística, isto é, ao feio. Ao retomar o pensamento estético-político de Schiller, Nietzsche entende que a contradição entre a cultura e a barbárie tem a ver com a ruptura, na esfera política, entre o conteúdo - o povo - e a forma - o Estado.

Não obstante, a cisão entre conteúdo e forma, entre interior e exterior, na esfera política, é consequência desta mesma ruptura no homem, o que está relacionado com uma equivocada concepção de cultura (Kultur) que predomina nesta nação. Nas palavras do filósofo: "[...] uma tendência à erudição [Gebildetheit] sumamente ambígua e em todo caso antinacional que se chama hoje na Alemanha, com perigosa equivocidade, cultura" (NIETZSCHE, 2011a, p. 642). O termo Gebildetheit consiste em um neologismo pouco usual que provavelmente foi tomado de Wagner, mais especificamente de sua obra Über das Dirigierem ${ }^{2}$ (Leipzig, 1869). Com o respectivo termo, Nietzsche pretende ressaltar o caráter abstrato de um tipo de formação eminentemente teórica, cultivada pelos homens cultos e doutos da Alemanha, quando se afirma a distância entre esta formação teórica de uma verdadeira formação, concreta e viva, que afeta diretamente o povo.

Nietzsche atribui este tipo de educação ao demasiado cultivo da interioridade em detrimento da exterioridade, do conteúdo em detrimento da forma, o que dissolve, no homem, a harmonia entre forma e conteúdo, entre exterior e interior. Cindido e debilitado, o alemão adquiriu uma espécie de aversão a todo tipo de imposição de formas objetivas e, de acordo com o filósofo, "[...] um medo descomunal da palavra 'convenção' e sem dúvida também da coisa convencional" (2011b, 
p. 713). Não obstante, o cultivo em demasia da interioridade, para Nietzsche, constitui um perigo iminente:

Repudiam eles com franca ironia o sentido da forma - posto que já tem o sentido do conteúdo: com efeito, são o famoso povo da interioridade [Innerlichkeit]. Agora bem, há também um famoso perigo inerente a esta interioridade: 0 perigo de que $o$ conteúdo mesmo, que se supõe que exteriormente nem pode ser visto, termine por evaporar-se [...] (2011b, p. 714, grifo do autor).

Os alemães, o povo da interioridade, do desprezo pela forma e do cultivo demasiado do conteúdo, podem extirpar o próprio conteúdo. Em outros termos, na medida em que não agem para o exterior, mas para o interior, os alemães não conseguem agir como um povo, mas somente como indivíduo isolado. Segundo Nietzsche, "[...] as belas fibras não estão enlaçadas em um nó comum", e, logo, “[...] a ação visível não é a ação total e a autorrevelação deste interior, mas tão só uma tentativa débil ou torpe de alguma fibra de tomar por uma vez, em aparência, o lugar do todo" (2011b, p. 714).

Enquanto sobrepuja a forma e a exterioridade, o cultivo demasiado da interioridade pode acabar com a interioridade. Nesse sentido, ao se opor às recentes tendências unificadoras do Estado prussiano, o filósofo afirma: "[...] o que anelamos, mais ardentemente que a restauração da unidade política, é a unidade alemã naquele supremo sentido, a unidade do espírito alemão e da vida alemã após a destruição do contraste entre forma e conteúdo, entre interioridade e convenção" (NIETZSCHE, 2011b, p. 715, grifo do autor). Contra a formação da unidade política do estado, Nietzsche propõe, ao modo do Estado estético de Schiller, uma unidade de estilo na formação alemã (eine Stileinheit der deutschen Bildung). Tal empresa, portanto, deve ter início no combate ao tipo de formação teórica que predomina na Alemanha moderna, designada por Nietzsche, em sua primeira extemporânea, de "formação de filisteu" (2011a, p. 645).

A formação de filisteu se apresenta como uma força inibidora da autêntica formação alemã (deutsche Bildung) e, dessa forma, um "inimigo interno" do povo alemão. Em outros termos, na medida em que sua ampla disseminação desenvolve, no alemão, a falsa ideia de ter uma cultura, esta tendência à erudição se mostra perigosa para a constituição do povo alemão, pois impede o surgimento de uma autêntica formação alemã e, consequentemente, de uma verdadeira cultura alemã. Os responsáveis pela disseminação e manutenção desse tipo de formação teórica são os "filisteus da formação" (Bildungsphilister) (NIETZSCHE, 2011a, p. 645), uma classe de homens eruditos e de natureza essencialmente antiestética, mas que, a despeito disso, considera-se artista e homem da cultura. 
Segundo Nietzsche, a palavra filisteu "[...] designa o contrário do filho das musas, do artista, do verdadeiro homem da cultura" (2011a, p. 645). O que difere esta noção geral de filisteu do filisteu da formação é o fato de este "ter a ilusão de que é filho das musas e homem de cultura" (2011a, p. 645), enquanto interfere em questões estéticas e culturais, pois acredita que “[...] sua 'formação' é justamente a viva expressão da verdadeira cultura" (2011a, p. 645). Mas de que modo o autêntico filisteu, homem alheio às Musas, converte-se em filisteu da formação e toma gosto pela arte e pelas questões em torno da estética e da cultura? Em obra póstuma, da época da redação da primeira extemporânea, o jovem filólogo tece algumas observações acerca do surgimento desta nova classe de filisteu, a do filisteu da formação:

O filisteu é justamente o ä $\mu о v \sigma o \varsigma$ [alheio às Musas]: é notável observar como ele apesar disso quer intervir em questões estéticas e culturais. Creio que o que serviu aqui de intermediário tem sido o pedagogo: ele, que por ofício se ocupava da Antiguidade clássica, e que pouco a pouco acreditou que por isso também devia ter um gosto clássico (NIETZSCHE, 2007, p. 103, grifo do autor).

Num primeiro momento, Nietzsche identifica o pedagogo como o elo entre o filisteu e o filisteu da formação. O ofício da pedagogia, por exigir o contato com a antiguidade clássica e com a autêntica cultura dos gregos, leva o filisteu não só à ilusão de que possui um gosto artístico, mas também à de que este gosto é clássico. Não obstante, ele não percebe a distinção entre uma autêntica formação artística, como a dos gregos do período clássico, e a erudição artística moderna. Em outro apontamento póstumo, de 1873, Nietzsche esboça uma nova hipótese sobre a origem do filisteu da formação, na qual reconhece no erudito o intermediário entre 0 autêntico filisteu e o da formação:

Origem do filisteu da formação [Entstehung des Philisters der Bildung]. Em si a formação sempre se reduz a círculos muito exclusivos. O autêntico filisteu se mantém distante deles. $\mathrm{O}$ erudito se faz de intermediário, ele acreditava na Antiguidade clássica e valorava os artistas como tipos suspeitos. Hegel pôs em circulação nas universidades muita estética. O público dos "Almanaques" é o público de sempre, jornais da tarde. Nos anos cinquenta os realistas, Julian Schmidt. Pouco a pouco se forma o público das conferências populares, é como um poder, tem simpatias, pressupostos etc. [...] (NIETZSCHE, 2007, p. 116).

Com efeito, Nietzsche reconhece no erudito o elo entre o filisteu e o filisteu da formação. São escritores, jornalistas, artistas e outros homens cultos que, por ignorar sua condição mesquinha de filisteu, tomam sua erudição como expressão viva de uma cultura autêntica ou, nos termos do próprio filósofo, sentem-se firmemente convencidos "[...] de que sua 'formação' é justamente a viva expressão da verdadeira cultura alemã" (2011a, p. 645). A ampliação das discussões sobre estética nas universidades, realizada por professores como Hegel, com a influência do realismo literário, bem como por escritores e jornalistas, como Julian Schmidt, ${ }^{3}$ que, por 
meio de almanaques e periódicos, levaram a arte e a crítica da arte ao grande público dos jornais, faz com que se "forme", aos poucos, o público das conferências populares e, com ele, a perigosa confusão entre a tendência à erudição e a cultura.

Na Alemanha moderna, afirma Nietzsche, o tipo do filisteu da formação está por toda parte e, aonde quer que vá, tem a impressão de si mesmo no contato frequente com as pessoas cultas de sua espécie. Também se reconhece nas instituições públicas e nos centros escolares, de cultura e de arte, que se organizam em consonância com sua erudição e de acordo com suas necessidades. Da constante impressão de si mesmo em todos os lugares, o filisteu da formação "[...] deduz uma unidade de estilo na formação alemã, enfim, uma cultura" (NIETZSCHE, 2011a, p. 646). Haja vista que a cultura pressupõe "[...] uma diversidade que conflua na harmonia de um único estilo" (NIETZSCHE, 2011a, p. 646), ele toma aquela unidade da impressão de si mesmo como uma unidade de estilo na formação, ou seja, como uma autêntica cultura. Nietzsche considera que a uniformidade constatada pelo filisteu da formação não consiste em uma unidade de estilo, mas, pelo contrário, corresponde à barbárie, e escreve:

O que vê ao seu redor são necessidades exatamente iguais e opiniões similares; aonde vai, lhe envolve de imediato a atadura de uma convenção tácita acerca de muitas coisas, em particular os assuntos da religião e da arte: esta imponente uniformidade, este tutti uníssono que, sem mediar voz de mando, estala ao instante, lhe induz a crer que aqui há uma cultura. Mas pelo fato de ter um sistema, o filisteíssimo sistemático e predominante não é todavia cultura, e nem sequer má cultura, mas seguirá sendo só o contrário, isto é, barbárie com fundamentos consistentes (2011a, p. 646).

Com efeito, a imponente uniformidade da formação de filisteu se confirma no círculo cada vez mais amplo de homens semelhantes a ele. Por onde quer que vá, depara-se com uma rígida convenção e padronização de ideias e opiniões consoantes a sua, seja em questões estéticas ou religiosas. No entanto, o que o filisteu da formação toma por cultura é justamente o seu contrário, a barbárie, ainda que sistematizada. Para Nietzsche, tal processo de uniformidade e padronização desse tipo de formação ocorre quando se exclui e se recusa o verdadeiro estilo:

Pois toda essa unidade da impressão que constantemente nos salta aos olhos em toda pessoa culta da Alemanha atual só chega a ser unidade por meio de exclusão e negação, consciente ou inconsciente, de todas as formas e exigências artisticamente produtivas de um verdadeiro estilo [wahren Stils] (2011a, p. 645).

O sentimento de unidade na formação de filisteu é apenas aparente. Trata-se de conformidade e consonância de atos e opiniões, mas não de uma verdadeira unidade estilística. A unidade em relação à formação filisteia, que, segundo Nietzsche, constantemente salta aos olhos do alemão, é por negar e excluir aquilo que é condição para a cultura: a unidade de estilo (Einheit des Stiles). 
Por unidade de estilo, Nietzsche entende uma totalidade, uma forma geral para a qual as partes individuais confluam de modo a constituir uma unidade estilística, isto é, uma cultura objetiva e verdadeira. Ao negar as formas e as exigências artísticas de um verdadeiro estilo, o filisteu da formação nega o princípio formador tanto do homem quanto do povo e da cultura. Assim, se Nietzsche entende a cultura como unidade de estilo artístico em todas as manifestações da vida de um povo, isso só é possível se partir de um critério estilístico objetivo como parâmetro para a ação dos homens individuais. Em outros termos, cada homem, ao agir de acordo com um único estilo objetivo, constitui um povo e reafirma a totalidade estilística que é a cultura. Na medida em que suas ações negam qualquer critério estilístico objetivo, o filisteu da formação não constitui uma cultura, mas seu oposto, uma "não cultura" (Nicht-Kultur) ou, quando muito, uma "barbárie estilizada" (stilisirten Barbarei) (NIETZSCHE, 2011a, p. 646).

Desse modo, no que se refere ao filisteu da formação, ainda que haja certa similaridade entre as suas ações e opiniões, tal semelhança só tem a ver com o conteúdo, pois, no tocante à forma, não se pode dizer o mesmo. Em outros termos, as ações do filisteu da formação nunca concorrem para um todo estilístico, isto é, não ultrapassam o caráter individual e subjetivo para constituir uma unidade estilística; dessa forma, não há uma cultura. Segundo Nietzsche: "Se lhe dá [ao filisteu da formação] a liberdade de eleger entre uma ação conforme a um estilo e a oposta, agarra sempre a última, e, como a agarra sempre, todas suas ações ficam marcadas com o selo negativamente uniforme. Neste selo reconhece o caráter da 'cultura' alemã por ele patenteada" (2011a, p. 646). Logo, por negar repetidamente qualquer estilo objetivo, o filisteu da formação acaba por desenvolver um sistema coerente de ações negativas, que Nietzsche designará de um "sistema da não cultura" (System der Nicht-Kultur) (2011a, p. 646), pois, segundo o filósofo, ele passa a ter "precisamente por cultura o que nega a cultura" (2011a, p. 646), isto é, a barbárie: confusão caótica de todos os estilos ou ausência de um estilo.

A aversão do filisteu pela ideia de convenção e pela ideia de forma se torna manifesto na literatura alemã moderna, marcada pelo constante processo de dilapidação da língua alemã em nome de uma linguagem do "tempo atual" (Jetztzeit). As raízes dessa tendência estão na influência que a filosofia hegeliana exerceu sobre o filisteu da formação. Nietzsche destaca:

Uma filosofia que, entre pregas e franjas, ao estilo das transparências de $\mathrm{Coos},{ }^{4}$ encobria o credo filisteu de seu autor, inventou ademais uma fórmula para divinizar a vida cotidiana: esta filosofia falava da racionalidade de todo o real e, assim, captou as simpatias do filisteu da formação, a quem também lhe agradam as pregas e franjas, mas que, sobretudo, só se concebe a si mesmo como real e trata sua realidade como medida e razão do mundo (2011a, p. 647). 
Com o idealismo hegeliano, surge a ideia de que a linguagem deve ser a expressão racional e subjetiva do seu tempo, um tempo fugaz com o qual Hegel designou a modernidade. ${ }^{5}$ Antes de Nietzsche, Schopenhauer já havia se posicionado contra esta tendência moderna.

Schopenhauer acusa os filósofos idealistas de terem introduzido na Alemanha esta linguagem da "atualidade", caracterizada pelo estilo afetado e prolixo ao qual designou stile empesé. ${ }^{6}$ Fichte foi o responsável por iniciá-lo; Schelling, por aperfeiçoá-lo, e Hegel, por levá-lo ao extremo. ${ }^{7}$ Por isso, desencadeou-se um processo progressivo de dilapidação da língua alemã em nome da linguagem da "atualidade": "Nobre atualidade", afirma Schopenhauer, "magníficos epígonos, um gênero que cresceu com o leite materno da filosofia hegeliana"; por escreverem de modo pesado e confuso, Schopenhauer se refere a esses filósofos como "paquidermes do estilo" e acrescenta, de maneira enérgica: "Fora, paquidermes, fora! Isto é a língua alemã! Nela se expressaram homens, nela cantaram grandes poetas e escreveram grandes pensadores [...]" (2009, p. 553-554, grifo do autor).

Para Schopenhauer, o cultivo desse estilo da "atualidade", na Alemanha, é um indício de barbárie e decadência do gosto, cuja causa está relacionada ao abandono do ensino das línguas antigas neste país. O filósofo escreve: "Mas, se alguma vez, tal e como ameaça nossa época, deixem-se de ensinar as línguas antigas, surgirá uma nova literatura constituída de escritos tão bárbaros, vulgares e indignos como jamais houve" (SCHOPENHAUER, 2009, p. 571). Cada vez mais mutilada e empobrecida, afirma o filósofo, a língua alemã "[...] vai degenerando pouco a pouco em um miserável jargão" (SCHOPENHAUER, 2009, p. 571).

O declínio do ensino das línguas antigas também fomenta cada vez mais o mercado das traduções das obras clássicas, o que, para Schopenhauer, também é um sintoma da iminente barbárie alemã. Em Parerga e Paralipomena, o filósofo considera a tradução feita em 1830 para o alemão do Corpus Juris (Corpo de lei) ${ }^{9}$ como "[...] um sinal inequívoco da ignorância na base de toda erudição que é a língua latina; isto é, um sinal de barbárie" (SCHOPENHAUER, 2009, p. 498-499). A tradução para o alemão de obras antigas é um péssimo sintoma, segundo o filósofo, que, ao chegar a esse extremo, afirma: "[...] então adeus ao humanismo, ao gosto nobre e ao sentido elevado! A barbárie volta apesar das ferrovias, da eletricidade e dos dirigíveis" (SCHOPENHAUER, 2009, p. 498-499).

Em contraste com essa tendência literária da "atualidade", Schopenhauer destaca o engenho, a sabedoria e o rigor com que os seus antepassados literatos trataram a língua alemã e lamenta que: "[...] a eles seguem em nossos dias uma geração de rascunhadores rudes, ignorantes e incapazes que, com suas forças e união, fazem negócio destruindo aquela antiga obra de arte com a dilapidação das palavras" (SCHOPENHAUER, 2009, p. 553). Unidos em nome da fama e do dinheiro, os escritores alemães 
da "atualidade" mantêm-se cúmplices do grosseiro anseio popular por uma linguagem do "tempo atual" (Jetztzeit). Segundo Schopenhauer, "[...] uma grande quantidade de escritores vive exclusivamente da extravagância do público de não querer ler nada além do que se imprime hoje: os jornalistas (Journalisten)" (2009, p. 514).

No entanto, a despeito do alto apreço do público em relação à linguagem do "tempo atual", Schopenhauer afirma: “[...] não existe maior erro que crer que a última palavra pronunciada é sempre a mais correta, que todo escrito com posteridade é uma melhora do que se escreveu antes, e que toda transformação é um progresso" (2009, p. 515). Ademais, para o autor de $O$ mundo como vontade e representação, "[...] o novo raramente é o bom; porque o bom é o novo só por um breve tempo" (SCHOPENHAUER, 2009, p. 517). Nessa perspectiva, o que torna latente a diferença entre a grande literatura, como a dos clássicos alemães, da literatura vulgar dos alemães da "atualidade" é, sobretudo, o seu poder de permanência no tempo. Foi por meio do estudo atento dos clássicos, cujo procedimento poético visa à transfiguração da realidade em um estilo artístico ideal e objetivo, que Goethe se tornou um clássico e eternizou a sua poesia, procedimento oposto ao dos escritores da "atualidade", cujo estilo subjetivo visa a expressar a fugacidade do "tempo atual". Quando se alinha ao classicismo de Goethe, Schopenhauer considera a subjetividade no estilo um defeito nativo da Alemanha moderna:

A subjetividade é um defeito estilístico que hoje em dia se faz cada vez mais frequente devido ao estado decadente da literatura e ao abandono das línguas antigas, mas que somente é nativo da Alemanha. Consiste em que ao escritor lhe basta saber ele mesmo o que opina e quer dizer; o leitor já verá como averiguá-lo (2009, p. 517).

Para Schopenhauer, escrever subjetivamente é como criar um monólogo, quando, na verdade, o dever do escritor é estabelecer um diálogo o mais claro e objetivo possível com o leitor. Dessa maneira, deve-se evitar a prolixidade na escrita e, para tanto: "[...] o estilo não deve ser subjetivo, mas objetivo; para isso é necessário colocar as palavras de modo que obriguem diretamente o leitor a pensar exatamente o mesmo que o autor pensou" (SCHOPENHAUER, 2009, p. 517, grifo do autor).

$\mathrm{Na}$ esteira da crítica schopenhaueriana da linguagem, Nietzsche considera que a ausência de uma unidade estilística na Alemanha decorre, sobretudo, do fato de que o alemão moderno já não tem apreço e não cultiva a língua alemã falada, o que compromete a instituição de um estilo alemão e, por conseguinte, de uma cultura alemã. Em sua primeira extemporânea, o autor destaca:

Falta aqui um terreno natural, o apreço, o manejo e o cultivo artístico da linguagem falada. Posto que isto, como os próprios termos "conversa de salão", "sermão", "discurso parlamentário" expressam, não constituiu, todavia, um estilo nacional em todas as manifestações públicas, ademais, nem sequer se chegou a sentir a necessidade de que haja um estilo [...] (NIETZSCHE, 2011a, p. 681). 
Quando negligencia o caráter objetivo da língua, indiferente aos seus aspectos formais e normativos, cada indivíduo, autonomamente, regula o seu modo de falar de acordo com suas necessidades. A falta de rigor e os maneirismos linguísticos são indícios do pouco apreço que o alemão tem por sua língua materna bem como do seu descompromisso com a busca de um estilo artístico autenticamente alemão. Como Schopenhauer, Nietzsche associa essa autonomia no modo de falar do alemão com a dilapidação da linguagem na literatura alemã moderna:

[...] e posto que todos aqueles que falam na Alemanha não foram além de alguns ingênuos experimentos com a língua, o caso é que o escritor não tem nenhuma norma unitária e sim certo direito de lutar por sua conta com a língua: daí provém, como consequência, a dilapidação sem limites da língua alemã do "tempo atual" [deutschen Sprache der Jetztzeit], que Schopenhauer descreveu de maneira mais enérgica (NIETZSCHE, 2011a, p. 681).

Ao principiar na dilapidação sem limites da língua, os defensores da linguagem alemã do "tempo atual" se caracterizam pela oposição radical à tradição, em particular ao estilo dos grandes escritores da língua alemã, como Lessing, Winckelmann, Goethe, Schiller, aos quais Nietzsche se refere como os "nossos clássicos" [unsere Klassiker]. Quando se refere a Schopenhauer, o jovem filósofo escreve:

Se isto segue assim - disse em certa ocasião [Schopenhauer] -, no ano de 1900 já não se entenderá bem os clássicos alemães (deutschen Klassiker), posto que a única língua alemã que se conhecerá será o jargão miserável do nobre "tempo atual" (Jetztzeit) (NIETZSCHE, 2011a, p. 681).

Segundo Nietzsche, a opinião desses novos "árbitros da língua e da gramática alemãs" do "tempo atual” é a de que o estilo desses escritores é ultrapassado e, por isso, não pode servir de parâmetro para os escritores atuais. Ao seguir essa sugestão, afirma: “[...] os nossos clássicos não podem seguir sendo modelo de nosso estilo [unseren Stil], porque empregam uma grande quantidade de termos, expressões e construções sintáticas que nós já perdemos” (2011a, p. 681).

Enquanto rejeita o tratamento rigoroso e artístico constatado no estilo dos escritores clássicos da língua alemã, surge, na Alemanha moderna, uma nova voga literária, cuja marca principal é a constante experimentação e dilapidação da língua alemã na busca incessante do novo, enfim, do que é mais "atual". Em tom pejorativo, Nietzsche denomina este novo estilo alemão de estilo jornalístico (Zeitungsstiles). Os escritores desse novo estilo são recebidos pelos homens cultos da Alemanha do século XIX como os "novos clássicos alemães" (der neuen deutschen Klassiker) (NIETZSCHE, 2011a, p. 683) e, nesse sentido, são eleitos os novos modelos do estilo alemão. Entre esses "novos clássicos alemães", Nietzsche destaca David Strauss, o escritor que será o tema de sua primeira extemporânea. 
Primeiramente, entende-se que o polêmico escrito sobre o famoso escritor alemão não é conduzido por motivos estritamente pessoais, ainda que tais motivos sejam incontestáveis. ${ }^{10}$ Grosso modo, Strauss não é o objeto da preocupação nietzschiana e tampouco o seu livro, A antiga e a nova fé, mas, sim, a fama que se assomou ao escritor e o êxito obtido pela obra. ${ }^{15} \mathrm{Em}$ um texto do ano de 1873, Nietzsche escreve: "Para nós o livro de Strauss não é um acontecimento, mas só o seu êxito. Nele não há nenhuma ideia que tenha valor e que se possa considerar boa e nova" (2007, p. 207). Se, no que tange à matéria, o livro de Strauss não apresenta nada que seja digno de atenção, o sucesso do autor e o êxito do livro em meio à opinião pública são, para Nietzsche, acontecimentos dignos de nota, na medida em que se revelam como sintomas de uma cultura em declínio. Em texto publicado postumamente, lê-se: "Schopenhauer diria de Strauss: é um autor que não vale a pena ser folheado, e muito menos ser estudado: exceto para aqueles que querem medir o grau da estupidez atual" (NIETZSCHE, 2007, p. 208).

À vista disso, o ataque de Nietzsche a Strauss ocorre em duas vias críticas: primeiramente, ao "devoto", ou seja, ao seu pensamento, e, em seguida, ao "escritor", isto é, ao seu estilo. Em linhas gerais, é não apenas por expressar pensamentos perigosos acerca da filosofia, da ciência, da arte e da religião que Strauss compromete a formação alemã, mas também pela forma com que expressa tais pensamentos; é pelo estilo, ou melhor, pela falta de unidade de estilo em seus escritos. Isso porque, para Nietzsche, esta falta na obra de Strauss é não apenas indício do declínio cultural em que se encontra a Alemanha do século XIX, mas, também, uma ameaça iminente ao próprio espírito alemão.

Como um típico filisteu da formação, Strauss é um homem culto e de tendência científica, porém de "natureza totalmente antiestética" (unaesthetische Natur) (NIETZSCHE, 2007, p. 208). No entanto, a despeito disso, como um típico filisteu da formação, Strauss também arroga a si o direito de ser chamado de "clássico". No tocante aos anseios do autor de A antiga e nova fé, Nietzsche se empenha em provar que Strauss não é, como se pensa, um prosista clássico, mas essencialmente moderno. Primeiramente, porque a obra de Strauss não corresponde ao princípio clássico do totum ponere ${ }^{16}$ o que, em linhas gerais, afirma que sua obra é destituída de proporções harmoniosas, logo, não constitui um todo orgânico e coeso, como deveria ser uma obra clássica. Ainda que se leve em conta o nexo lógico entre suas partes, segundo Nietzsche, o livro de Strauss se apresenta fragmentado e pouco orgânico, na medida em que, segundo o filósofo, não há uma ligação coerente entre as questões que dão nome às partes do livro. ${ }^{11}$ 
Um segundo motivo pelo qual Strauss não é um clássico, segundo Nietzsche, é o fato de ele não ter um estilo, o que lhe obriga a adquiri-lo de outros. Nietzsche escreve:

Vamos revelar um segredo: nosso magister nem sempre sabe o que prefere ser, se Voltaire ou Lessing, mas de nenhuma maneira quer ser um filisteu, e se for possível, é seguro que prefira ser os dois, Lessing e Voltaire - para que se cumpra o que está aí escrito: "não tinha nenhum caráter, mas que quando queria tê-lo, antes tinha que adquiri-lo" (2011a, p. 678).

A incapacidade para a unidade de estilo consiste na característica geral do filisteu da formação, logo, é também a de Strauss. Seu modo de proceder consiste em produzir um mosaico de estilos inspirados em autores autenticamente clássicos e geniais, como Voltaire e Lessing, enquanto se deduz que Strauss também é um gênio e um clássico. Nietzsche deduz a falta de estilo de Strauss de sua falta de caráter, o que faz dele um ator: "[...] quando se senta a escrever, põe uma cara que não muda, como se estivesse pousando para um retrato, e mostra ora a cara lessinguiana, ora a volteriana [...] tenho-o por um ator que faz o papel de gênio ingênuo e de clássico" (NIETZSCHE, 2011a, p. 678), não obstante, afirma Nietzsche, ele é um mau ator, pois, tudo aquilo que imita, imita mal (2011a, p. 678).

A ausência de caráter num escritor é, segundo Nietzsche, um defeito grave, na medida em que o impele a mostrar sempre aquilo que não é, ao passo que o escritor de caráter sempre se apresenta como é, de maneira sincera, simples e ingênua. A simplicidade do estilo (Simplicität des Stil), portanto, tende a ser uma característica central do gênio ingênuo, logo, é um atributo necessário para todo escritor que deseje um dia ser um clássico. Nietzsche destaca: "Esta simplicidade tem sido sempre a característica do gênio, o único que tem o privilégio de expressar-se com sensibilidade, naturalidade e ingenuidade [...]", e acrescenta: "Mas o escritor genial não se revela somente na simplicidade e no caráter peremptório da expressão: sua força excessiva o leva a jogar com os conteúdos, ainda que estes sejam perigosos e difíceis" (2011a, p. 679). Os gênios verdadeiramente ingênuos, afirma Nietzsche, são suficientemente fortes para fazer da multiplicidade de conteúdos uma simplicidade de estilo. Eles não precisam de nada que já não tenham; não usam máscaras e estão sempre com "pouca roupa", mas, ainda assim, aparecem mais solenemente que qualquer outro escritor trajado. "Mas com isso tem feito muito o escritor, ao obrigar os seus leitores a vê-lo mais solene que qualquer outro escritor que vai vestido com mais roupa. É o caminho para chegar a ser algum dia um clássico" (NIETZSCHE, 2011a, p. 679).

Diante disso, como atribuir o título de "novos clássicos alemães" a escritores cuja característica principal reside na refutação da simplicidade e da ingenuidade inerentes ao estilo dos autênticos "clássicos alemães"? A incoerência parece ser ain- 
da maior quando se pretende o estilo jornalístico do "tempo atual" como um modelo para o estilo alemão, pois como extrair um estilo modelar de uma literatura cuja característica principal é o caos estilístico, isto é, a refutação de toda e qualquer norma unitária da linguagem ou unidade estilística objetiva em nome da autonomia subjetiva do autor? Nietzsche escreve:

Pois bem, o traço mais característico dessa pseudocultura do filisteu da formação é ver como logra para si o conceito de clássico e de escritor exemplar - ele, que só se mostra forte na hora de rechaçar um estilo de cultura verdadeira e artisticamente rigoroso e que, com essa insistência e rechaço, logra uma uniformidade na expressão que quase parece ser uma unidade de estilo (2011a, p. 682).

Não obstante, a impressão de que com a ausência de um estilo rigoroso obtém-se um novo estilo e uma nova cultura, como se vê, é apenas aparente, haja vista que de uma qualidade negativa não é possível se instituir uma cultura positiva. $\mathrm{O}$ contato diário do alemão com a linguagem de jornais e revistas faz com que, gradativamente, ele incorpore esta linguagem do "tempo atual". Destarte, na mesma proporção em que o "novo estilo" se fortalece, a língua alemã padece. Na perspectiva de Nietzsche, as responsáveis pela disseminação e oficialização do estilo jornalístico e da formação douta do filisteu da formação são as instituições de formação (Bildungs-anstalten) alemãs que estão organizadas de acordo com as tendências eruditas do primeiro e, nesse sentido, atuam de acordo com as suas necessidades.

Em Sobre o futuro de nossas instituições de formação, escrito do início de 1872, Nietzsche (2011, p. 483) considera que a impotência para a fundação de uma autêntica cultura alemã advém da decadência das instituições de formação, que, em sua época, apresentam-se dominadas por tendências político-pedagógicas perigosas, de caráter eminentemente democrático. Tais tendências, argumenta Nietzsche, apresentam-se sob dois impulsos aparentemente contrários, contudo, igualmente nocivos em seus efeitos: "[...] por um lado, o impulso até a maior ampliação da formação possível; por outro lado, o impulso de redução e enfraquecimento dessa formação" (NIETZSCHE, 2011c, p. 483, grifo do autor). Em outros termos, o alargamento da educação para o maior número de pessoas possível, como previsto na primeira tendência, só é possível por intermédio do abandono das pretensões supremas e soberanas da educação contidas na segunda.

Quando se persegue o objetivo de modernizar as instituições alemãs de formação, isto é, de conformá-las à época, esses impulsos desviam-se "das sublimes tendências originárias de sua fundação" (NIETZSCHE, 2011, p. 483), enquanto contrariam os propósitos da natureza, cuja lei necessária consiste no estreitamento e na concentração da formação de poucos. Distante da natureza, tais impulsos só podem dar conta de fundar uma cultura fictícia (erlogene Kultur), jamais uma 
cultura autêntica. Mas quais são os riscos de se promover ampliação e redução dos meios educacionais? E por que tal tendência deve ser evitada?

Primeiramente, a ampliação dos meios educacionais tem como consequência a barbárie na medida em que inviabiliza uma educação rigorosa, cujos princípios são o hábito e a obediência. Diante dessas duas tendências pedagógicas, tais princípios teriam sido substituídos pela ilusão da emancipação racional, que, segundo Nietzsche, "[...] debilita a educação a tal ponto que não pode mais fundar nenhum privilégio nem garantir nenhum respeito. Entendida assim, esta tendência à educação universal só pode ter como fim a barbárie" (2011c, p. 487). Em segundo lugar, o processo de ampliação deve necessariamente desembocar em um processo de erudição vazio e sem sentido. Nietzsche escreve:

[...] me parece que, por muitos outros lados diferentes, se entoa outra canção, desde logo menos sonora, mas com não menos ênfase; a saber, a canção da redução da educação. Em todos ambientes eruditos, só se sussurra ao ouvido esta canção: que com o ansiado uso do erudito ao serviço de sua ciência, sua formação se voltará cada vez mais casual e inverossímil (2011c, p. 487, grifo do autor).

Todavia, a despeito do caráter ficcional da cultura alemã de sua época, cuja fundação ocorre sobre impulsos inaturais, há, segundo Nietzsche, uma tendência contrária que consumará, no futuro, uma radical transformação nos meios e métodos de ensino e, consequentemente, nas instituições de ensino. De acordo com Nietzsche:

[...] se adivinhará a vitória algum dia a uma tendência educativa já existente, ainda que neste momento pudesse não ser querida, estimada, nem estar estendida. Mas ela vencerá, como creio com a maior das confianças, porque conta com a maior e mais poderosa das companheiras de aliança: a natureza (2011c, p. 488).

Na luta entre o natural e o inatural, isto é, entre as tendências de ampliação e redução dos meios formativos, ambas inaturais, e a exigência da própria natureza no tocante ao estreitamento e à concentração dos meios de formação, a natureza, segundo Nietzsche, mostrar-se-á implacável.

Como contrapartida a essa tendência, encontra-se no ideal classicista de educação estética do homem um firme aporte teórico para as reflexões pedagógicas do jovem Nietzsche, que, tal como seus predecessores, também acredita que a valorização da formação erudita e de caráter eminentemente teórico, tal como é praticada nas instituições de ensino alemãs de seu tempo, só pode contribuir para o caos e para a barbárie, jamais para a fundação de uma autêntica cultura. Em texto de publicação póstuma, escrito no verão de 1872 e no início de 1873, o filósofo defende a hipótese de uma formação intuitiva em detrimento de uma formação essencialmente conceitual: "A formação não é necessariamente conceitual [begriffliche], mas sobretudo é intuitiva [anschauende]" (2007, p. 354. grifo do autor). 
Nessa perspectiva, Nietzsche entende que a educação de um povo para a formação deve ser entendida como um acostumar-se a bons modelos (gute Vorbilder) e a uma formação de necessidades nobres (Bildung edler Bedürfnisse).

De outro modo, em detrimento de uma formação abstrata e conceitual, Nietzsche sugere que o homem seja formado de maneira intuitiva por meio de uma educação estética (aesthetischer Erziehung), que consiste, em última análise, no contato com a arte dos clássicos antigos e dos clássicos alemães. Nessa acepção, Schiller, Goethe e Winckelmann são, para Nietzsche, modelos imprescindíveis para fazer da moderna educação alemã uma educação eminentemente estética, o que significa dizer uma educação clássica:

Uma vez mais necessitamos desses mesmos guias, esses mesmos mestres, nossos clássicos alemães, para que o bater das asas de suas aspirações até a antiguidade leve também a nós... até a terra da nostalgia, a Grécia. Dessa relação - a única possível entre nossos clássicos e a educação clássica -, não se vislumbra nada entre os velhos muros das escolas de bacharelado (NIETZSCHE, 2011c, p. 507).

Contra as tendências modernas de formação, Nietzsche sugere uma pedagogia clássica pautada no estudo meticuloso da língua materna, a partir dos escritos dos mestres clássicos alemães, como proposta de renovação dos meios educacionais na Alemanha, que se encontrava, naquele momento, absolutamente contaminada pelos impulsos modernos de ampliação e redução.

O símbolo maior desse tipo de formação ampliada e reduzida, segundo Nietzsche, é o jornalismo. Escreve ele: "Efetivamente, no jornalismo [Journalistik] confluem as duas orientações; a ampliação e a redução da formação se dão aqui a mão. $\mathrm{O}$ jornal ocupa diretamente o lugar da formação [...]" (2011c, p. 499). No âmbito da Alemanha moderna, a figura do jornalista, o "escravo do instante", substituiu o gênio da espécie, "[...] o guia para todas as épocas, o que redime do instante" (NIETZSCHE, 2011c, p. 499). Em outros termos, a filosofia e a arte foram substituídas pelo jornal e pelas novelas da moda, "[...] cujo estilo leva em si o repugnante selo da barbárie educativa atual" (NIETZSCHE, 2011c, p. 499).

No centro da crítica nietzschiana às instituições de formação alemãs de sua época, está o problema da linguagem. Na avaliação de Nietzsche, as escolas de bacharelado alemãs deixaram de se comprometer com a formação do homem quando deixaram de lado a rígida disciplina linguística ao desvalorizar e desfigurar a língua alemã. Para o filósofo, o aprendizado profundo da língua materna é uma condição, ou melhor, um "dever sagrado", para todo aquele que almeja ao ensino superior. Em tom de exortação, Nietzsche escreve: "Levar a sério vossa língua! Quem não consegue sentir nisso um dever sagrado, não terá em si nem sequer o gérmen para uma educação superior" (2011c, p. 502). A maneira como a língua materna é tratada por um povo, afirma Nietzsche, diz muito acerca do seu apreço pela arte, 
bem como de sua aptidão para perseguir a cultura: "Se não chegais a tanto como a sentir asco ante certas palavras e certas distorções linguísticas de nosso condicionamento jornalístico então podeis deixar já de perseguir a cultura” (2011c, p. 502).

A língua materna é o meio para realizar a verdadeira formação estética e moral do homem bem como para construir uma autêntica cultura. Nesse ponto de vista, Nietzsche atribui ao professor de alemão, no bacharelado, a incumbência de chamar a atenção dos alunos sobre as distorções linguísticas atuais em que os proíbe de utilizar, em seu vocabulário, tais distorções. Além disso, afirma Nietzsche, o mesmo professor deveria se utilizar dos autores clássicos alemães, percorrendo “[...] linha a linha com quanto cuidado e rigor há que tomar as expressões quando no coração se tem o sentimento artístico correto e diante dos olhos a completa compreensibilidade de tudo o que escreve" (2011c, p. 502). Segundo o filósofo, o ensino rigoroso e exaustivo da língua alemã é um modo de separar os alunos mais bem dotados e aptos para o ensino superior dos menos dotados, que desistirão no meio do caminho.

Porém, não é este o método que Nietzsche vê aplicado nas escolas de bacharelado alemãs. Nelas, o ensino rigoroso da língua materna a partir dos escritores clássicos fora substituído pelas características repugnantes da estética jornalística: "Na escola de bacharelado se imprimem as repugnantes características de nossa estética jornalística sobre os espíritos não formados dos adolescentes" (NIETZSCHE, 2011c, p. 503). Nessas escolas, tanto a língua alemã quanto os autores clássicos são banalizados pelos próprios professores. Para Nietzsche, estes são os responsáveis por disseminar um "grosseiro querer-mal-interpretar [Mißverstehen-wollen] dos clássicos alemães" (2011c, p. 503), pois afirmam efetuar uma crítica estética, quando o que fazem não é outra coisa senão uma "descarada barbárie" (2011c, p. 502).

O problema desse tipo de abordagem dos clássicos alemães não é apenas a banalização de suas obras e da própria língua materna, mas o falso sentimento de autonomia e autossuficiência que é produzido no aluno. Em disciplinas como “composição em alemão", incita-se a personalidade do aluno, ou seja, sua própria individualidade. Nietzsche escreve: "A composição em alemão é uma chamada ao indivíduo" (2011c, p. 503). Ora, para o filósofo, incitar a personalidade e a originalidade do aluno na escrita é cometer um afrontamento diante da sagrada língua materna e, nesse sentido, é cometer "um pecado contra o espírito" (2011c, p. 503).

Conforme Nietzsche, a originalidade e a personalidade são atributos que poucos homens maduros conseguem ter, portanto, incitar um adolescente a ter personalidade é um grande equívoco da educação alemã de sua época. Ao se considerar que um adolescente é capaz de compor um texto literário original e com persona- 
lidade, as instituições de formação também consideram que esse adolescente tem o direito de emitir opiniões e juízos próprios sobre os assuntos e as pessoas mais sérias. Para Nietzsche, tais instituições cometem um equívoco ao ensinar a autonomia quando deveriam ensinar a obediência. O filósofo alemão escreve:

[...] um ensino de verdade deveria reprimir com todos seus esforços as ridículas pretensões de uma autonomia de juízo e habituar o jovem a uma obediência estrita sob o cetro do gênio. Está-se pressupondo a capacidade de representar o grande a uma idade em que qualquer frase, falada ou escrita, constitui um barbarismo (2011c, p. 504).

Segundo Nietzsche, ao fomentar esse tipo de formação, as instituições de educação alemãs engendram uma situação perigosa para o futuro. Ele enumera os males que o culto da personalidade e a autonomia de juízo na formação escolar geraram no ambiente literário e artístico alemão de sua época, que são: a produção apressada e vaidosa, a completa falta de estilo, a ausência de caráter e refinamento na expressão, a perda de todo cânon estético e, por fim, o prazer na anarquia e no caos. Esses são, em resumo, os traços literários que Nietzsche chama de jornalismo estético ou, numa palavra, a barbárie. As instituições de formação alemãs, na acepção nietzschiana, ainda não possuem condições de implantar uma rigorosa $\mathrm{e}$ verdadeira formação, a que, segundo o filósofo, consiste, antes de tudo, na obediência e no hábito, especialmente no que se refere à língua materna.

Para o filósofo alemão, a tendência jornalística, ao prescindir dos ensinamentos dos grandes clássicos alemães, como Goethe, Schiller, Winckelmann e Lessing, desviou-se da única via que conduz à autêntica formação clássica, a saber, a antiguidade, pois "[...] toda a assim chamada educação clássica só tem um ponto de partida são e natural: o hábito artisticamente sério e rigoroso no uso da língua materna" (NIETZSCHE, 2011c, p. 507, grifo do autor). Na tarefa de formação, os clássicos são imprescindíveis, pois são como guias e mestres que conduzirão o aluno à verdadeira formação e à cultura.

O ensino da língua materna é uma chave de acesso ao espírito do povo. Destarte, a concessão à cultura estrangeira, aos hábitos e aos estilos de outros povos é, segundo Nietzsche, o inimigo mais perigoso do espírito. Conservar a língua alemã é, em última análise, conservar a cultura e o espírito alemão. Nietzsche escreve: "Com força nos aferramos ao espírito alemão que se manifestou na Reforma alemã e na música alemã e que se demonstrou na extraordinária audácia e rigor da filosofia alemã e na fidelidade recentemente provada do soldado alemão" (2011c, p. 510, grifo do autor). Entretanto, o que se promove nas instituições de formação alemãs não é o cultivo da língua materna, mas o seu extermínio.

Ao fomentar a extirpação da língua alemã, as instituições contribuem para o desaparecimento do próprio espírito alemão. Em obra de 1873, o filósofo escreve: 
"O alemão será logo um mosaico de palavras sem alma e com uma sintaxe europeia. Perdemos cada vez mais a linguagem e deveríamos saber que valor tem para nós - o alemão! Conseguimos um império alemão no momento em que estamos a ponto de deixar de sermos alemães" (NIETZSCHE, 2007, p. 432). Próximo do pensamento de Burckhardt, ${ }^{12}$ Nietzsche entende a linguagem como a expressão mais direta e ideal do espírito de um povo. Posto isso, ao dilapidar a língua alemã, o alemão aniquila aquilo que faz dele o que ele é: o espírito alemão. Escreve o filósofo:

Pois quem pecou contra a língua alemã profanou o mysterium de nossa germanidade: é somente ela que por meio de toda a mescla e as modificações das nacionalidades e dos costumes, como por milagre metafísico, se salvou a si mesma e desse modo salvou também o espírito alemão. É somente ela que garante ademais esse espírito para o futuro, sempre que não pereça ela mesma nas mãos perversas do "presente” (NIETZSCHE, 2011a, p. 686).

Como produto da intuição humana, a linguagem guarda um potencial artístico e inconsciente de um povo que é ativado e ampliado pela atividade do estilista ou do orador. É, portanto, no aperfeiçoamento dos elementos artísticos inconscientes da língua que as artes retórica e poética despertam no homem imagens inconscientes de sua coletividade ao mesmo tempo em que dissipa a representação ilusória da individuação. Então, ao dilapidar a língua alemã, o alemão aniquila aquilo que faz dele o que ele é: o próprio espírito alemão.

\section{Notas}

1 As citações da obra de Nietzsche foram feitas a partir da Sämtliche Werke. Kritische Studienausgabe organizad G. Colli e M. Montinari, publicada pela editora Walter de Gruyter, 1980 em 15 volumes. Sempre que necessário, recorremos à tradução espanhola dos escritos de juventude, de J. B. Llinares, Diego Sánchez Meca e Luis E. de Santiago Guervós, publicado pela editora Tecnos, Madrid, 2011.

2 Cf. Nietzsche, 2011, p. 642.

3 Heinrich Julian Schmidt (1818-1886) foi um escritor, jornalista, crítico e historiador da literatura prussiano. Em Leipzig, junto com Gustav Freytag, outro jornalista atacado por Nietzsche, Schmidt editou o periódico Die Grenzbotende, de 1848 a 1861 . Neste ano, mudou-se para Berlim, onde trabalhou como editor-chefe do Berliner allgemeine Zeitung, um dos jornais mais influentes da Alemanha do período.

4 Dentre os trajes utilizados pelas cortesãs de Atenas, o mais conhecido é a coa, que recebe esse nome da ilha grega de Coos.

5 Acompanhamos a interpretação de Habermas (2000, p. 09) acerca do conceito de modernidade. Para o filósofo de Frankfurt, Hegel foi o primeiro filósofo a desenvolver um conceito claro de modernidade, isto é, a elevar o termo modernidade a um estatuto conceitual. Segundo ele, a utilização hegeliana desse conceito teria ocorrido num contexto sobretudo histórico, no qual o irromper dos "novos tempos" foi identificado com a expressão "tempos modernos". No entanto, se, para o Ocidente cristão, a expressão "novos tempos" remete a uma experiência escatológica do tempo, configurada na espera pelo Juízo Final, o conceito secular de tempos modernos expressa, segundo Habermas, a convicção de um futuro que já se iniciou e que se faz presente, em suma, de uma época orientada para o novo. Com o conceito de modernidade, Hegel teria traduzido filosoficamente uma experiência inédita do tempo entendido como passagem e transição para um novo período. O Zeitgeist (espírito do tempo) hegeliano expressa justamente essa caracterização do presente "como uma transição que se consome na consciência da aceleração e na experiência da heterogeneidade do futuro" (HABERMAS, 2000, p. 10). Modernidade, portanto, não é uma época, mas o modo de se perceber tempo de uma dada época.

6 Cf. Schopenhauer (2009, p. 534-535). 
7 Cf. Schopenhauer (2009, p. 529).

8 Nietzsche reproduz literalmente esta última passagem no parágrafo 12 de sua primeira extemporânea.

9 O Corpus Juris (Corpo de lei) é a base da jurisprudência latina e foi publicado entre 529 e 534 d. C., por ordens do imperador Justiniano I.

${ }^{10}$ Nesse sentido, defendemos que, a despeito de toda discussão em torno do contexto e dos motivos que supostamente levaram Nietzsche a se ocupar de um escritor como David Strauss em sua primeira extemporânea, o alcance crítico e filosófico deste escrito não deve ser minimizado por abordagens biográficas que o reduzem à condição de uma mera "encomenda" ou ao cumprimento do dever de um discípulo para com o seu mestre, Wagner. De fato, na época da redação dessa extemporânea, o jovem Nietzsche ainda se encontrava muito ligado a Wagner, o que torna possível que sua investida contra o recente livro do teólogo alemão David Strauss seja fruto de seu afã em ser útil ao mestre. Wagner tinha um acerto de contas com Strauss por este ter se posicionado a favor do músico Fran Lachner, seu predecessor na corte de Luis II da Baviera. Não obstante a legitimidade dos referidos dados históricos, entendemos que estes não podem comprometer a autenticidade e o profundo alcance filosófico deste escrito, na medida em que nele nos deparamos com motivos autenticamente nietzschianos, como a crítica da cultura e o antissocratismo, já desenvolvido em escritos anteriores, como em $O$ nascimento da tragédia.

${ }^{11}$ David Strauss publica Das alte und neue Glaube em 1872, sua última obra, mas também a de maior sucesso, ganhando seis edições em menos de dois anos. A referida obra apresenta ao leitor uma espécie de justificativa do itinerário intelectual do autor, desde o abandono daquilo que designa por "antiga fé", a doutrina cristã, até sua adesão à "nova fé", que, em linhas gerais, consiste numa visão materialista da história justificada hegelianamente.

${ }^{12}$ A noção de totum ponere é proveniente da estética clássica, particularmente das artes poética e retórica. Nessa acepção, a realização do belo na obra de arte depende da capacidade do artista em criar uma totalidade, uma obra de arte em que as partes estejam ordenadas de modo a compor um todo harmônico. O ideal clássico do totum ponere influenciará de maneira decisiva a crítica nietzschiana aos escritores alemães de sua época e, de modo particular, ao teólogo e escritor David Strauss em sua primeira consideração extemporânea.

${ }^{13}$ As questões que nomeiam as quatro partes de $A$ antiga e nova fé são as seguintes: primeira questão - somos ainda cristãos?; segunda questão - temos ainda religião?; terceira questão - como concebemos o mundo?; e quarta questão - como ordenamos nossa vida? (STRAUSS, 1900).

${ }^{14}$ Em Reflexões sobre a história, o historiador alemão Jacob Burckhardt afirma: "[...] os idiomas são a expressão mais direta, mais total e altamente específica do espírito dos povos, sua imagem ideal, a forma mais duradoura, na qual os povos depositam a substância da sua vida espiritual, encerrada principalmente nas palavras de seus grandes poetas e pensadores" (1961, p. 63). É notória a influência das ideias do historiador da cultura Jacob Burckhardt no pensamento de Nietzsche, que participou como ouvinte das conferências que Burckhardt proferiu na Universidade da Basileia das quais resultou a obra citada. Não obstante, foi não apenas a concepção burckhardtiana da linguagem que chamou a atenção do jovem filólogo, mas também a sua concepção de "Estado como obra de arte". Nesse sentido, Burckhardt toma o estado como a uma criação artística consciente de um povo e não um acidente da história. Tal concepção é decisiva para a elaboração da concepção de cultura como unidade de estilo artístico de Nietzsche. Em A cultura do renascimento na Itália, Burckhardt escreve: "Assim como, em sua maioria, os Estados italianos constituíam obras de arte - ou seja, eram produto da reflexão, criações conscientes, embasadas em manifestos e bem calculados fundamentos -, também sua relação entre si e com o exterior tinha de ser uma obra de arte” (2009, p. 112).

\section{Referências}

BURCKHARDT, J. A cultura do renascimento na Itália: um ensaio. Trad. Sérgio Tellaroli. São Paulo: Companhia das letras, 2009.

. Reflexões sobre a História. Trad. Leo Gilson Ribeiro. Rio de Janeiro: Zahar, 1961.

HABERMAS, Jürgen. O discurso filosófico da modernidade. Trad. Luiz Sérgio Repa e Rodnei Nascimento. São Paulo: Martins Fontes, 2000.

NIETZSCHE, Friedrich. Consideraciones Intempestivas, I: David Strauss, el Confesor Escritor. In: _. Obras completas V. 1: escritos de juventude. Trad. Joan. B. Llinares, Diogo Sánchez Meca e Luis E. de Santiago Guervós. Madrid: Techos, 2011a. p. 641-694. 
Consideraciones Intempestivas, II: De la Utilidad y los Inconvenientes de la historia para la vida. In: Obras completas V. 1: escritos de juventude. Trad. Joan. B. Llinares, Diogo Sánchez Meca e Luis E. de Santiago Guervós. Madrid: Techos, 2011b. p. 695-748.

Sobre el futuro de nuestras instituciones educativas. In: Obras completas V. 1: escritos de juventude. Trad. Joan. B. Llinares, Diogo Sánchez Meca e Luis E. de Santiago Guervós. Madrid: Techos, 2011c. p. 483-542. 2007. v. 1 .

Fragmentos póstumos (1869 - 1874). Trad. Luis E. de Santiago Guervós. Madrid: Techos,

NIETZSCHE, F. Sämtliche Werke. Kritische Studienausgabe. Hg. G. Colli e M. Montinari. Berlin: Walter de Gruyter, 1980, 15v.

SCHOPENHAUER, Arthur. Parerga y paralipómena II. Trad. Pilar López de Santa María. Madrid: Trotta, 2009.

STRAUSS, D. F. La antigua y la nueva fe. Trad. Ramón Ibáñez. Madrid: F. Sempere y Compañía Editores, 1900. 